\title{
UPAYA MENINGKATKAN KOMPETENSI PEDAGOGIK GURU SDN TASIKAGUNG DALAM MENYELENGGARAKAN PEMBELAJARAN YANG MENDIDIK MELALUI SUPERVISI AKADEMIK TEKNIK KUNJUNGAN KELAS PADA SEMESTER I TAHUN PELAJARAN 2017/2018
}

\author{
Kusmiyatun \\ SDN Tasikagung, Kec. Rembang, Kab. Rembang \\ e-mail : kusmiyatunrembang@yahoo.com
}

\begin{abstract}
The purposes of this research are describing academic supervision with class visiting technique to the teachers on the Elementary School of Tasikagung in implementation educative learning on the first semester of 2017/2018 year academic and analyzing academic supervision with class visiting technique on the first semester of 2017/2018 year academic to the teachers on the Elementary School of Tasikagung pedagogic competency in implementation educative learning. The type of this research is School Action Research (SAR). This research is taken place on Elementary School of Tasikagung, Sub District of Rembang, Regency of Rembang. The subjects of this research are the teachers of the class and the subject matters ones on the Elementary School of Tasikagung on the first semester of 2017/2018 year academic. The subjects of this research are consists of 9 civil officer teachers and 4 non regular teachers. Technique of collecting data of this research is non test technique, consist of observation and documentation. The instruments of collecting data of this research are the sheets of observation and the camera application on the hand phone. Technique of analyzing data of this research is comparative description. The procedure of this research is cycle model that consist of 4 steps that are plan, action, observation and reflection. The results of this research are 1) academic supervision with class visiting technique is a direct observation with ideal position on observing the learning, 2) academic supervision with class visiting technique is a direct observation with out interview and intervention to the teachers who implement the learning, 3) academic supervision with class visiting techniques are an individual by the head master according to the class visiting schedule and a group with the interested teachers as reference to implement the educative learning, 4) academic supervision with class visiting technique increases the teachers pedagogic competency in implementation educative learning.

Keywords: Pedagogic Competency, Teachers, Learning, Academic Supervision, Class Visiting.
\end{abstract}

\begin{abstract}
Abstrak
Tujuan dalam penelitian ini adalah mendeskripsikan supervisi akademik teknik kunjungan kelas pada guru SDN Tasikagung dalam menyelenggarakan pembelajaran yang mendidik pada Semester I Tahun Pelajaran 2017/2018 dan menganalisis supervisi akademik teknik kunjungan kelas pada Semester I Tahun Pelajaran 2017/2018 terhadap kompetensi pedagogik guru SDN Tasikagung dalam menyelenggarakan pembelajaran yang mendidik.Jenis penelitian ini adalah Penelitian Tindakan Sekolah (PTS). Penelitian ini dilakukan di SDN Tasikagung, Kecamatan Rembang, Kabupaten Rembang. Penelitian ini berlangsung pada awal Semester I Tahun Pelajaran 2017/2018. Subyek penelitian ini adalah Guru Kelas dan Guru Mata Pelajaran SDN Tasikagung pada Semester I Tahun Pelajaran 2017/2018. Subyek penelitian terdiri dari 9 orang guru dengan status Pegawai Negeri Sipil (PNS) dan 4 orang guru dengan atatus Guru Tidak Tetap (GTT). Teknik pengumpulan data dalam penelitian ini adalah teknik nontes, meliputi pengamatan dan dokumentasi kegiatan penelitian. Alat pengumpulan data dalam penelitian ini adalah lembar
\end{abstract}


pengamatan dan aplikasi kamera pada hand phone. Teknik analisis data dalam penelitian ini adalah deskriptif komparatif. Prosedur penelitian ini adalah Model Siklus yang terdiri dari 4 tahap, yaitu perencanaan, tindakan, pengamatan dan refleksi. Hasil penelitian ini adalah 1) Supervisi akademik teknik kunjungan kelas dilakukan dengan mengamati kegiatan pembelajaran secara langsung pada posisi yang ideal untuk melakukan pengamatan, 2) Supervisi akademik teknik kunjungan kelas dilakukan dengan mengamati kegiatan pembelajaran secara langsung tanpa wawancara maupun intervensi terhadap guru yang sedang menyelenggarakan pembelajaran tersebut, 3) Supervisi akademik teknik kunjungan kelas dilakukan kepala sekolah seorang diri sebagai supervisor sesuai dengan jadwal kunjungan kelas maupun bersama-sama dengan guru-guru yang berminat sebagai acuan dalam menyelenggarakan pembelajaran yang mendidik, 4) Supervisi akademik teknik kunjungan kelas meningkatkan kompetensi pedagogik guru dalam menyelenggarakan pembelajaran yang mendidik.

Kata Kunci: Kompetensi Pedagogik, Guru, Pembelajaran, Supervisi Akademik, Kunjungan Kelas.

\section{PENDAHULUAN}

Dalam Peraturan Pemerintah Republik Indonesia Nomor 74 Tahun 2008 tentang Guru yang dimaksud guru adalah pendidik profesional dengan tugas utama mendidik, mengajar, membimbing, mengarahkan, melatih dan mengevaluasi peserta didik pada pendidikan anak usia dini jalur pendidikan formal, pendidikan dasar dan pendidikan menengah. Selanjutnya dalam Peraturan Menteri Pendidikan Nasional Nomor 16 Tahun 2007 tentang Standar Kualifikasi Akademik dan Kompetensi Guru yang dimaksud Kualifikasi Akademik Guru SD/MI adalah Guru SD/MI atau bentuk lain yang sederajat harus memiliki kualifikasi akadmeik pendidikan minimum diploma empat (D-IV) atau sarjana (S1) dalam bidang pendidikan SD/MI atau psikologi yang diperoleh dari program studi yang terakreditasi dan Kompetensi Guru SD/MI adalah standar kompetensi yang dikembangkan secara utuh dari empat kompetensi utama, yaitu pedagogik, kepribadian, sosial dan profesional.

Sesuai dengan kedua dasar hukum tersebut di atas, Guru dan Kompetensi merupakan 2 hal yang saling berkaitan dan tidak dapat dipisahkan, khususnya kompetensi pedagogik. Tolok ukur seorang guru dan kompetensi pedagogiknya adalah pembelajaran dan hasil belajar dimana keduanya juga saling berkaitan dan tidak terpisahkan. Pembelajaran yang berkualitas bagus dan bermakna bagi peserta didik akan mendapat hasil belajar yang memuaskan bagi peserta didik. Demikian juga sebaliknya dimana pembelajaran dengan kualitas yang terbatas dan tidak bermakna bagi peserta didik memperoleh hasil belajar yang mengecewakan.

Dalam Peraturan Pemerintah Republik Indonesia Nomor 74 Tahun 2008 tentang Guru, kompetensi pedagogik merupakan kemampuan guru dalam pengelolaan pembelajaran peserta didik yang sekurang-kurangnya meliputi: 1) pemahaman wawasan atau landasan kependidikan, 2) pemahaman terhadap peserta didik, 3) pengembangan kurikulum atau silabus, 4) perancangan pembelajaran, 5) pelaksanaan pembelajaran yang mendidik dan dialogis, 6) pemanfaatan teknologi pembelajaran, 7) evaluasi hasil belajar dan 8) pengembangan peserta didik untuk mengaktualisasikan berbagai potensi yang dimilikinya.

Dalam Undang-Undang Republik Indonesia Nomor 20 Tahun 2003 tentang Sistem Pendidikan Nasional, pembelajaran adalah proses interaksi peserta didik dengan pendidik dan sumber belajar pada suatu lingkungan belajar. 
Di SDN Tasikagung, Kecamatan Rembang, Kabupaten Rembang, Guru Kelas maupun Guru Mata Pelajaran dalam menyelenggarakan pembelajaran kurang memperhatikan tahap-tahap dalam pembelajaran. Pada kegiatan pembuka, guru langsung masuk pada materi sesuai dengan buku teks. Pada kegiatan inti, guru aktif, verbalistik dan dominan dengan partisipasi peserta didik yang terbatas. Pada kegiatan penutup, guru mengabaikan refleksi, umpan balik, tindak lanjut dan persiapan pada pertemuan berikutnya.

Sesuai dengan hasil pengamatan dalam pembelajaran dan wawancara dengan guru, kompetensi pedagogik guru dalam menyelenggarakan pembelajaran yang mendidik termasuk kurang berkualitas dengan nilai rata-rata sebesar 1,97. Pada kegiatan pembuka dan kegiatan penutup, pembelajaran termasuk kurang berkualitas. Pada kegiatan inti, pembelajaran termasuk cukup berkualitas. Ada 7 guru dengan pembelajaran cukup berkualitas dan 6 guru lainnya dengan pembelajaran yang kurang berkualitas.

Kompetensi pedagogik guru dalam menyelenggarakan pembelajaran yang mendidik pada hakikatnya diawali sejak perancangan pembelajaran, dilanjutkan dengan pengembangan komponenkomponen dalam pembelajaran kemudian dipraktikan dalam pembelajaran sesuai dengan karakteristik peserta didik dan tujuan pembelajaran itu sendiri. Sesuai dengan hal tersebut, penulis sebagai kepala sekolah melakukan supervisi akademik dengan teknik kunjungan kelas sebagai tindak lanjut terhadap pembinaan dalam penyelenggaraan pembelajaran yang mendidik. Dengan kunjungan kelas, guru mengetahui kesesuaian antara pembelajaran yang dipraktikan dengan pembelajaran yang mendidik.

\section{METODE PENELITIAN}

Jenis penelitian ini adalah Penelitian Tindakan Sekolah (PTS). Penulis merupakan kepala sekolah yang melakukan tindakan kepala guru dengan supervisi akademik teknik kunjungan kelas untuk mengamati kegiatan pembelajaran secara langsung.

Penelitian ini dilakukan di SDN Tasikagung, Kecamatan Rembang, Kabupaten Rembang. Tempat penelitian beralamat di Jalan Pelabuhan. Tempat penelitian terdiri dari 2 kampus, yaitu kampus utama dan kampus tambahan yang berjarak \pm 50 meter. Penelitian ini berlangsung pada awal Semester I Tahun Pelajaran 2017/2018. Penelitian berlangsung selama tiga bulan, sejak bulan Agustus sampai bulan Oktober.

Subyek penelitian ini adalah Guru Kelas dan Guru Mata Pelajaran SDN Tasikagung pada Semester I Tahun Pelajaran 2017/2018. Subyek penelitian terdiri dari 9 orang guru dengan status Pegawai Negeri Sipil (PNS) dan 4 orang guru dengan status Guru Tidak Tetap (GTT).

Teknik pengumpulan data dalam penelitian ini adalah teknik nontes. Teknik nontes meliputi pengamatan dan dokumentasi kegiatan penelitian. Teknik nontes digunakan untuk mengumpulkan data kompetensi pedagogik guru dalam menyelenggarakan pembelajaran yang mendidik. Alat pengumpulan data dalam penelitian ini adalah lembar pengamatan dan aplikasi kamera pada hand phone. Teknik analisis data dalam penelitian ini adalah deskriptif komparatif. Data kompetensi pedagogik guru dalam menyelenggarakan pembelajaran yang mendidik pada setiap siklus dideskripsikan dan dibandingkan dengan indikator keberhasilan tindakan. Prosedur penelitian ini adalah Model Siklus yang terdiri dari 4 tahap, yaitu perencanaan, tindakan, pengamatan dan refleksi. 


\section{HASIL DAN PEMBAHASAN}

\section{Siklus I}

Pada Siklus I, penulis melakukan kunjungan kelas seorang diri dan mengamati kegiatan pembelajaran yang sedang berlangsung, baik di dalam kelas, di laboratorium maupun di lapangan. Penulis melakukan pengamatan pada posisi yang ideal tanpa mengganggu pembelajaran yang sedang berlangsung. Penulis melakukan kunjungan kelas selama 1 minggu sesuai dengan materi dan tema yang ditentukan setiap guru.

Pada Siklus I, setiap guru sudah berupaya menyelenggarakan pembelajaran yang mendidik dengan memperhatikan tahap-tahap dalam pembelajaran, yaitu kegiatan pembuka, kegiatan inti dan kegiatan penutup. Sesuai hasil pengamatan terhadap kegiatan pembelajaran yang sedang berlangsung dengan lembar pengamatan diketahui pembelajaran termasuk kategori cukup mendidik (C) dengan nilai rata-rata sebesar 14,69.

\section{Siklus II}

Pada Siklus II, penulis melakukan kunjungan kelas bersama dengan guru yang berminat dan mengamati kegiatan pembelajaran yang sedang berlangsung, baik di dalam kelas, di laboratorium maupun di lapangan. Penulis dan guru-guru tersebut melakukan pengamatan pada posisi yang ideal tanpa mengganggu pembelajaran yang sedang berlangsung. Penulis melakukan kunjungan kelas selama 1 minggu sesuai dengan materi dan tema yang ditentukan setiap guru.

Pada Siklus II, setiap guru sudah berupaya menyelenggarakan pembelajaran yang mendidik dengan penguasaan materi yang semakin kuat, sehingga pembelajaran tidak hanya mengacu pada materi dan tema saja. Selain itu, setiap guru sudah berupaya menggunakan metode belajar dan media pembelajaran, sehingga pembelajaran menarik dan bervariasi. Sesuai hasil pengamatan terhadap kegiatan pembelajaran yang sedang berlangsung dengan lembar pengamatan diketahui pembelajaran termasuk kategori mendidik (B) dengan nilai rata-rata sebesar 21,92.

\section{Pembahasan}

Kompetensi pedagogik guru SDN Tasikagung dalam menyelenggarakan pembelajaran yang mendidik termasuk kurang berkualitas membutuhkan supervisi akademik. Oleh karena itu, penulis sebagai kepala sekolah kunjungan kelas untuk mengamati kegiatan pembelajaran secara langsung.

Kompetensi pedagogik guru dalam menyelenggarakan pembelajaran yang mendidik pada hakikatnya diawali sejak perancangan pembelajaran, dilanjutkan dengan pengembangan komponenkomponen dalam pembelajaran kemudian dipraktikan dalam pembelajaran sesuai dengan karakteristik peserta didik dan tujuan pembelajaran itu sendiri. Oleh karena itu, penulis mengawali dengan pembinaan tentang penyelenggaraan pembelajaran yang mendidik. Selanjutnya, setiap guru menentukan materi dan tema yang hendak disupervisi.

Pada penelitian ini, kunjungan kelas dilakukan hanya 1 kali untuk setiap guru dan berlangsung selama 1 minggu sesuai dengan jadwal kunjungan kelas untuk setiap siklusnya. Kunjungan kelas untuk mengamati kegiatan pembelajaran secara langsung tanpa wawancara maupun intervensi terhadap guru yang sedang menyelenggarakan pembelajaran tersebut.

Pada Siklus I, penulis melakukan kunjungan kelas seorang diri dan mengamati kegiatan pembelajaran yang sedang berlangsung, baik di dalam kelas, di laboratorium maupun di lapangan. Penulis melakukan pengamatan pada posisi yang ideal tanpa mengganggu pembelajaran yang sedang berlangsung. Setiap guru sudah berupaya menyelenggarakan pembelajaran 
yang mendidik dengan memperhatikan tahap-tahap dalam pembelajaran, yaitu kegiatan pembuka, kegiatan inti dan kegiatan penutup.

Pada Siklus II, penulis melakukan kunjungan kelas bersama dengan guru yang berminat dan mengamati kegiatan pembelajaran yang sedang berlangsung, baik di dalam kelas, di laboratorium maupun di lapangan. Penulis dan guru-guru tersebut melakukan pengamatan pada posisi yang ideal tanpa mengganggu pembelajaran yang sedang berlangsung. Setiap guru sudah berupaya menyelenggarakan pembelajaran yang mendidik dengan penguasaan materi yang semakin kuat, sehingga pembelajaran tidak hanya mengacu pada materi dan tema saja. Selain itu, setiap guru sudah berupaya menggunakan metode belajar dan media pembelajaran, sehingga pembelajaran menarik dan bervariasi.

Sesuai dengan hasil pengamatan terhadap kegiatan pembelajaran yang sedang berlangsung dengan lembar pengamatan diketahui pembelajaran termasuk kategori cukup mendidik (C) dengan nilai rata-rata sebesar 14,69 pada Siklus I dan pembelajaran termasuk kategori mendidik (B) dengan nilai rata-rata sebesar 21,92 pada Siklus II. Sesuai dengan data tersebut, maka indikator keberhasilan kinerja terpenuhi dimana nilai rata-rata kompetensi pedagogik guru SDN Tasikagung dalam menyelenggarakan pembelajaran yang mendidik termasuk kategori mendidik (B).

Sesuai dengan analisis hasil pengamatan terhadap kegiatan pembelajaran yang sedang berlangsung dengan lembar pengamatan diketahui 5 orang guru atau $38,46 \%$ sudah menyelenggarakan pembelajaran yang termasuk kategori mendidik (B) pada Siklus I dan 6 orang guru atau $46,15 \%$ sudah menyelenggarakan pembelajaran yang termasuk kategori sangat mendidik (A), 7 orang guru atau 53,85\% sudah menyelenggarakan pembelajaran yang termasuk kategori mendidik (B) pada Siklus II. Sesuai dengan data tersebut, maka indikator keberhasilan kinerja terpenuhi dimana persentase kompetensi pedagogik guru SDN Tasikagung dalam menyelenggarakan pembelajaran yang mendidik memenuhi minimal $75 \%$ dari keseluruhan subyek penelitian.

Penulis menganalisis data penelitian kompetensi pedagogik guru dalam menyelenggarakan pembelajaran yang mendidik dan kategorinya sesuai dengan grafik dan tabel sebagai berikut: 


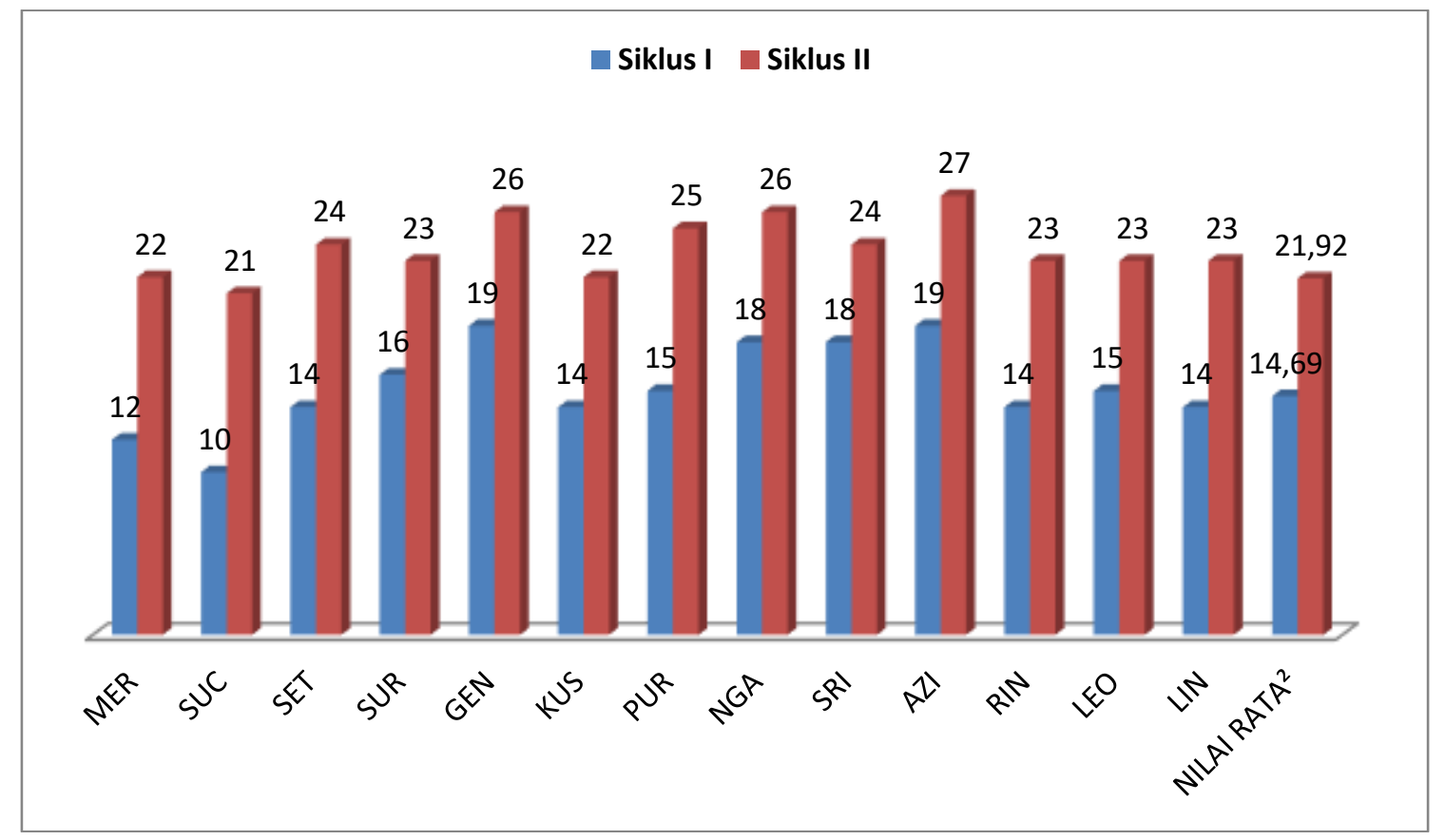

Grafik 1. Kompetensi pedagogik guru dalam menyelenggarakan pembelajaran yang mendidik.

Tabel 1. Kategori kompetensi pedagogik guru dalam menyelenggarakan pembelajaran yang mendidik.

\begin{tabular}{|c|l|c|c|c|}
\hline No & \multicolumn{1}{|c|}{ Nama } & $\begin{array}{c}\text { Kondisi } \\
\text { Awal }\end{array}$ & Siklus I & Siklus II \\
\hline 1 & Merina, S.Pd. & D & C & B \\
\hline 2 & Hj. Suci Hayaningrum, S.Pd. & C & C & B \\
\hline 3 & Setyowati, S.Pd.I & C & C & A \\
\hline 4 & Surini, S.Pd.SD. & C & C & A \\
\hline 5 & Genduk, S.Pd.SD. & C & B & B \\
\hline 6 & Kustutik, S.Pd.SD. & C & C & A \\
\hline 7 & Purwatiningsih, A.Ma.Pd. & D & C & B \\
\hline 8 & H. Ngabdul Basit, S.Pd. & C & B & A \\
\hline 9 & Sri Setyowati, S.Pd.SD. & C & B & A \\
\hline 10 & Aziz Winoto, S.Pd.SD. & C & B & A \\
\hline 11 & Rina Cahyaningrum, S.Pd. & D & C & B \\
\hline 12 & Leo Susetiawan, S.Pd. & D & C & B \\
\hline 13 & Lintang Yulia Martiana, S.Pd. & D & C & B \\
\hline & \multicolumn{1}{|c|}{ Kategori rata-rata } & D & C & B \\
\hline
\end{tabular}


Sesuai dengan analisis data penelitian di atas, kompetensi pedagogik guru meningkat dan penyelenggaraan pembelajaran termasuk kategori mendidik. Hal tersebut sesuai dengan tindakan yang dilakukan penulis terhadap setiap guru dimana guru mendapat pembinaan tentang penyelenggaraan pembelajaran yang mendidik dan mempunyai kesempatan melakukan kunjungan kelas untuk mengamati kegiatan pembelajaran secara langsung.

Penyelenggaraan pembelajaran yang mendidik sesuai dengan kompetensi pedagogik guru itu sendiri. Oleh karena itu, supervisi akademik sangat penting dan bermanfaat dalam meningkatkan kompetensi pedagogik tersebut. Dalam penelitian ini, penulis melakukan supervisi akademik dengan teknik kunjungan kelas. Pada Siklus I, kunjungan kelas dilakukan seorang diri oleh penulis sebagai supervisor. Pada Siklus II, kunjungan kelas dilakukan bersama-sama dengan setiap guru.

Penyelenggaraan pembelajaran yang mendidik sangat berkaitan dengan dengan peran guru dalam pembelajaran tersebut. Oleh karena itu, guru harus melakukan beberapa peran secara proporsional dalam pembelajaran tersebut sesuai dengan komponen-komponen dalam pembelajaran itu sendiri. Menurut Sanjaya (2008: 21-2133), peran guru dalam pembelajaran adalah sumber belajar, fasilitator, pengelola, demonstrator, pembimbing, motivator dan evaluator. Peran guru yang tidak proporsional dalam pembelajaran menjadikan guru sebagai komponen pembelajaran yang aktif dan dominan, sehingga pembelajaran menjadi pasif, tidak menarik dan tidak interaktif.

Pembelajaran yang mendidik ditandai dengan interaksi dalam komponenkomponen pembelajaran dan terdiri dari 3 tahap yang saling berkaitan dan berkelanjutan, yaitu kegiatan pembuka, kegiatan inti dan kegiatan penutup. Pada hakikatnya, penyelenggaraan pembelajaran yang mendidik diawali sejak perancangan pembelajaran, dilanjutkan dengan pengembangan komponen-komponen dalam pembelajaran kemudian dipraktikan dalam pembelajaran sesuai dengan karakteristik peserta didik dan tujuan pembelajaran itu sendiri. Sesuai dengan supervisi akademik kunjungan kelas, kompetensi pedagogik guru dalam menyelenggarakan pembelajaran yang mendidik semakin meningkat. Pada penelitian ini, peningkatan kompetensi pedagogik guru dalam menyelenggarakan pembelajaran yang mendidik memenuhi indikator keberhasilan tindakan, sehingga hipotesis penelitian terbukti benar dan tujuan penelitian tercapai.

\section{SIMPULAN}

1. Supervisi akademik teknik kunjungan kelas pada guru SDN Tasikagung dalam menyelenggarakan pembelajaran yang mendidik pada Semester I Tahun Pelajaran 2017/2018 dengan mengamati kegiatan pembelajaran secara langsung secara individual maupun bersama-sama dengan guru-guru lainnya tanpa wawancara maupun intervensi terhadap guru yang sedang menyelenggarakan pembelajaran tersebut.

2. Kompetensi pedagogik guru SDN Tasikagung dalam menyelenggarakan pembelajaran yang mendidik melalui supervisi akademik teknik kunjungan kelas pada Semester I Tahun Pelajaran 2017/2018 meningkat dan termasuk kategori mendidik (B) dengan nilai ratarata sebesar 21,92.

\section{Saran}

1. Guru supaya menguasai materi dan menggunakan metode belajar dan media pembelajaran yang beragam, sehingga penyelenggaraan pembelajaran yang 
mendidik menjadi budaya sekolah yang bermutu.

2. Kepala sekolah supaya melakukan supervisi akademik yang beragam dan berkelanjutan kepada setiap guru, sehingga kompetensi pedagogik guru semakin meningkat sesuai dengan kriteria yang diharapkan dalam Peraturan Menteri Pendidikan Nasional
(Permendiknas) Nomor 16 Tahun 2007 tentang Standar Kualifikasi Akademik dan Kompetensi Guru.

3. Sekolah supaya melengkapi media pembelajaran, baik jumlah, jenis maupun kualitasnya, sehingga menunjang penyelenggaraan pembelajaran yang mendidik.

\section{DAFTAR PUSTAKA}

Anonim. 2003. Undang-Undang Republik Indonesia Nomor 20 Tahun 2003 tentang Sistem Pendidikan Nasional. Jakarta: Kementrian Hukum dan Hak Asasi Manusia Republik Indonesia.

---. 2007. Peraturan Menteri Pendidikan Nasional Republik Indonesia Nomor 16 Tahun 2007 tentang Standar Kualifikasi Akademik dan Kompetensi Guru. Jakarta: Kementrian Hukum dan Hak Asasi Manusia Republik Indonesia.

---. 2008. Peraturan Pemerintah Republik Indonesia Nomor 74 Tahun 2008 tentang Guru. Jakarta: Kementrian Hukum dan Hak Asasi Manusia Republik Indonesia.

Hamdani. 2011. Strategi Belajar Mengajar. Bandung: Pustaka Setia.

Pidarta, Made. 2009. Supervisi Pendidikan Kontekstual. Jakarta: Rineka Cipta.

Rifa'i dan Anni, 2009. Psikologi Pendidikan. Semarang: UNNES Press.

Rusman. 2012. Model-Model Pembelajaran Mengembangkan Profesionalisme Guru. Jakarta: Raja Grafindo Persada.

Sanjaya, Wina. 2008. Strategi Pembelajaran Berorientasi Standar Proses Pendidikan. Jakarta: Kencana Prenada Media Group.

Suhardan, Dadang. 2010. Supervisi Profesional. Bandung: Alfabeta.

Suparlan. 2008. Membangun Sekolah Efektif. Ypgyakarta: Hikayat.

Susanto, Ahmad. 2014. Teori Belajar dan Pembelajaran di Sekolah Dasar. Jakarta: Kencana Prenada Media Group. 